\title{
Diversity of Arbuscular Mycorrhizal Fungi in the Rhizosphere of Solaris and Regent Grapevine Plants Treated with Bioproducts
}

\author{
L. Sas-Paszt*, S. Głuszek, E. Derkowska, B. Sumorok, J. Lisek, P. Trzciński, A. Lisek, M. Frąc, M. Sitarek, M. Przybył, \\ K. Górnik
}

Research Institute of Horticulture, Konstytucji 3 Maja 1/3, 96-100 Skierniewice, Poland

Submitted for publication: October 2019

Accepted for publication: March 2020

Key words: AMF, identification of spores, plant fertilisation, Vitis sp. L.

\begin{abstract}
The aim of this study was to identify the spores of arbuscular mycorrhizal fungi (AMF) in the rhizosphere of Solaris and Regent grapevine plants grafted onto SO4 rootstock and treated with bioproducts. The bioproducts Ausuma, Bioilsa, manure and BF Ekomix were tested and applied on their own, or combined with standard mineral fertilisation (NPK). The applied bioproducts contributed to an increase in the number of species of mycorrhizal fungi in the rhizosphere soil of the grapevines. The most frequently occurring AMF species was Claroideoglomus claroideum. Biopreparation BF Ekomix was a promising agent for increasing the number of AMF spores in the rhizosphere of Regent grapevines. In the rhizosphere of Solaris, a positive influence on the number of spores occurred after the application of Bioilsa.
\end{abstract}

\section{INTRODUCTION}

Poland has a temperate climate with relatively cold winters and warm summers. The average air temperatures are around $6^{\circ} \mathrm{C}$ to $8.5^{\circ} \mathrm{C}$ in a year, and the annual rainfall is between $500 \mathrm{~mm}$ and $700 \mathrm{~mm}$, of which snow constitutes only $5 \%$ to $20 \%$. Although Poland is situated in the coldest winegrowing area in Europe, the cultivation of grapevines has been gaining in popularity in recent years. Due to the change in climate and increase in average temperatures, the climatic conditions are becoming more favourable for grape growing in Poland (Kopeć, 2009), and in other countries that have not previously been associated with viticulture (Hannah et al., 2013; Gaidos, 2014). Lower temperatures during the vegetation period compared with those in southern European countries result in a lower sugar content in the fruit, higher acidity and larger amounts of polyphenolic compounds, which also depend on the cultivar (Tarko et al., 2008; Krośniak et al., 2009; Izajasz-Parchańska et al., 2014). The cultivars Solaris and Regent, commonly cultivated in Poland, are classified either as Vitis vinifera cultivars (Vitis International Variety Catalogue, 2016) or as inter-intraspecific hybrids (Theocharis et al., 2010). These cultivars are more resistant to frost than most of the original $V$. vinifera cultivars, and have low sensitivity to fungal diseases (Lisek et al., 2016).

Arbuscular mycorrhizal fungi (AMF) are a group of obligate symbionts belonging to Glomeromycota, which form mutualistic symbioses with about $80 \%$ of land plant species on Earth (Smith \& Read, 2008; Schüßler \& Walker, 2010). These fungi provide several benefits to host plants, including supplying water and mineral nutrients, such as phosphorus and nitrogen, to allow growth under inadequate nutrient supply (Nouri et al., 2014; Thirkell et al., 2016; Prasad et al., 2017). AMF are able to protect host plants against environmental stresses such as water stress, salinity and metal toxicity (Lenoir et al., 2016). The hyphae of these fungi have the ability to penetrate very small pores in the soil because they are thinner than plant roots (Allen, 2011). The hyphae and the glycoprotein glomalin produced by AMF are among the main soil-stability factors (Wright \& Upadhyaya, 1998; Zhang et al., 2016; Kohler et al., 2017). Mycorrhizal infection may affect the mineral nutrition of the host plant directly, by enhancing plant growth through nutrient acquisition by the fungus, or indirectly, by modifying transpiration rates and the composition of rhizosphere microflora (Marschner \& Dell, 1993).

Arbuscular mycorrhizal fungi also increase the resistance of grapevine plants to soil pathogens (Nogales et al., 2009) and limit the harmful effects of soil organisms, such as nematodes (Hao et al., 2012). Mycorrhizal fungi have been observed to affect the proteome of grapevine plants by modifying plant metabolism through changes in protein amounts (Cangahuala-Inocente et al., 2011). Application of arbuscular mycorrhizal fungi in the cultivation of grapevines helps to increase the amounts of anthocyanins, flavonols and other polyphenolic compounds in the plants (Torres et al., 2015).

Bioproducts contain one or several biologically active

*Corresponding author: E-mail address: lidia.sas@inhort.pl

Acknowledgements: The authors thank Prof. Janusz Btaszkowski from the Department of Plant Protection of the West Pomeranian University of Technology in Szczecin, for his help in identifying the arbuscular mycorrhizal fungi. This work was supported by the Ministry of Science and Higher Education of Poland (project no. 5.2.4., statutory activities) 
organic compounds (amino acids, vitamins, enzymes, plant hormones), as well as macro- and microelements (Tarozzi et al., 2008). The use of bioproducts in agriculture increases the growth and cropping of cultivated plants, and improves the quality of arable and degraded soils (Bhardwaj et al., 2014; Wezel et al., 2014; Sas-Paszt et al., 2015; Derkowska et al., 2017). A separate group of products stimulating plant growth and yield are bioproducts produced with live microorganisms or dead cells. These special bioproducts contain organic matter and various types of bacteria and fungi, especially mycorrhizal fungi, to stimulate the growth and yield of cultivated plants (Berg et al., 2013; Boyer et al., 2015; Sas-Paszt et al., 2015; Vassilev et al., 2015). Beneficial microorganisms as components of bioproducts stimulate root growth and the uptake of mineral ions, and can be parasitic, predatory or antagonistic towards plant pathogens (Mercado-Blanco \& Bakker, 2007).

It was found previously that the use of fertilisers or biostimulants, such as Ausma, Bioilsa and BF Ekomix, did not in any way affect the time of ripening of grapevine fruit of two cultivars, Solaris and Regent. There were no significant differences in the yields of both cultivars within single years. The only exceptions in those years were the higher marketable yields of Solaris treated with Bioilsa in 2014 and of Regent treated with NPK + manure in 2014 and 2015. No significant differences were found in the cumulative marketable yields in the years 2009 to 2015 between the untreated control and other combinations, neither in the case of the cultivar Solaris nor for Regent (Lisek et al., 2016).

Bio-physicochemical soil properties can significantly affect spore density, e.g. total AMF spore numbers decreased with increasing amounts of heavy metals in the soil (Del Val et al., 1999). Jansa et al. (2002) reveal that tillage has a significant influence on the sporulation of some species, and non-Glomus AMF tended to be more abundant in the notilled soil. In our study, the data revealed that the application of bioproducts in the cultivation of horticultural crops greatly influences species composition and abundance of spores of AMF in rhizosphere soil (Sumorok et al., 2011; L. SasPaszt, unpublished data). This is a first study of the influence of microbial bioproducts on the mycorrhizal biodiversity in grapevine cultivation. For this reason, determining the impact of bioproducts on the number of spores and species of AMF enables an assessment of their status in the soil treated with bioproducts. Therefore, the aim of this study was to determine the effects of bioproducts on the diversity of mycorrhizal fungal species and their abundance expressed by the number of spores formed by arbuscular mycorrhizal fungi in the grapevine root zone under plantation conditions.

\section{MATERIALS AND METHODS \\ Experimental design}

The experiments were conducted in the period 2012 to 2016 on two grapevine cultivars, Solaris and Regent, grafted onto rootstock SO4 ( $V$. berlandieri $x \quad V$. riparia), planted in the spring of 2008 in the Experimental Orchard of the Research Institute of Horticulture in Skierniewice (Central Poland) (latitude $51^{\circ} 57^{\prime} \mathrm{N}$, longitude $20^{\circ} 08^{\prime} \mathrm{E}$ ). The vineyards were located on a medium-quality pseudo-podsolic soil (graded
Class IV), slightly acidic ( $\mathrm{pH} 6.0$ ), containing (as \% DW): $2.37 \mathrm{~N}, 0.15 \mathrm{P}, 1.35 \mathrm{~K}, 0.22 \mathrm{Mg}, 1.64 \mathrm{Ca}$; microelements $\left(\mathrm{mg} \mathrm{kg}^{-1}\right): 3.2 \mathrm{~B}, 13.5 \mathrm{Cu}, 1084 \mathrm{Fe}, 96.6 \mathrm{Mn}$ and $11.8 \mathrm{Zn}$; and $1.3 \%$ of organic matter. The plants were trained in the Double Guyot system with 10 to 14 bud canes and a low (0.3 m to $0.4 \mathrm{~m})$ trunk. The spacing between the plants in a row was $1.25 \mathrm{~m}$, in inter-rows $2.7 \mathrm{~m}$, and the isolation strip between the plots was $1 \mathrm{~m}$ wide. The experiment was designed in randomised complete blocks with four replications and four plants in each (16 vines per treatment and cultivar). From 2013, the inter-rows were maintained under spontaneous vegetation and mowed several times during the season. Weeds under the vine canopies were removed by hand. During the growing season, one to two treatments were performed with pesticides containing mancozeb and sulphur. The experimental plots were not irrigated throughout the entire study period (Lisek et al., 2016).

The average sum of active temperatures (SAT) - sum of all, medium daily temperatures higher than $10^{\circ} \mathrm{C}$ in the period April to October - in Skierniewice in the period 2012 to 2016 was $2699^{\circ} \mathrm{C}\left(2012: 2730^{\circ} \mathrm{C}, 2013: 2553^{\circ} \mathrm{C}, 2014\right.$ : $\left.2851^{\circ} \mathrm{C}, 2015: 2694^{\circ} \mathrm{C}, 2016: 2667^{\circ} \mathrm{C}\right)$.

The average seasonal temperature in the period April to October in 2012 to 2016 was $14.3^{\circ} \mathrm{C}\left(14.4^{\circ} \mathrm{C}\right.$ in 2012 , $14.0^{\circ} \mathrm{C}$ in $2013,14.5^{\circ} \mathrm{C}$ in $2014,14.1^{\circ} \mathrm{C}$ in $2015,14.3^{\circ} \mathrm{C}$ in 2016). The average total annual precipitation amounted to $500 \mathrm{~mm}$ and ranged from $316 \mathrm{~mm}$ in 2015 to $680 \mathrm{~mm}$ in 2010. In the course of the study, the following minimum winter temperatures below $-20.0^{\circ} \mathrm{C}$ were recorded: $-23.0^{\circ} \mathrm{C}$ (6.01.2009); $-28.1^{\circ} \mathrm{C}(26.01 .2010) ;-22.3^{\circ} \mathrm{C}(2011-02-22)$; $-23.3^{\circ} \mathrm{C}$ (2012-02-04; and $-21.4^{\circ} \mathrm{C}$ (2013-03-24) (Lisek et al., 2016).

The ten experimental combinations were prepared and examined as follows:

1. Control combination - no NPK fertilisation and no application of bioproducts.

2. NPK fertilisation. Ammonium nitrate was used at $70 \mathrm{~g}$ per plant, granular triple superphosphate at $77.5 \mathrm{~g}$ per plant, and potassium sulphate at $97.5 \mathrm{~g}$ per plant. Mineral fertilisers were administered in the spring (April) of each year.

3. Ausma - plant product derived from steam-distilled pine needles (Biolat, Lithuania). Applied in the form of a foliar spray at a concentration of $0.1 \%$, at nine, six and three weeks before the fruit harvest.

4. NPK fertilisation + Ausma in doses as above, at nine, six and three weeks before the fruit harvest.

5. Bioilsa - commercial product of animal origin (ILSA Group Arzignano, Vicenza, Italy). Applied in the form of granules in an amount of $24 \mathrm{~g}$ per plant to the upper soil layer $(0 \mathrm{~cm}$ to $30 \mathrm{~cm})$ in the spring (April) of every year.

6. NPK fertilisation + Bioilsa applied in doses as above.

7. Fertigo - granulated manure (Dutch company Ferm-OFeed). Applied at a rate of $25 \mathrm{~L}$ per plot to the upper soil layer $\left(0 \mathrm{~cm}\right.$ to $30 \mathrm{~cm}$ ) (plot surface area $\left.-5 \mathrm{~m}^{2}\right)$ in April of every year.

8. NPK fertilisation + Fertigo manure applied in doses as above. 
9. BF Ekomix - commercial product of plant origin (AgroBio Products, Wageningen, Netherlands). Applied in the form of granules at a rate of $100 \mathrm{~g}$ per plant to the upper soil layer $(0 \mathrm{~cm}$ to $30 \mathrm{~cm})$ in the spring (April) of every year.

10. NPK fertilisation + BF Ekomix in doses as above.

In the autumn (September) of 2012, 2014 and 2016, samples of soil from the root zone of the Regent and Solaris grapevines were collected for the determination of fungal spore numbers in the rhizosphere soil, and subsequent taxonomic identification of the spores of AMF in the 2014 season. Soil samples were collected from a depth of $10 \mathrm{~cm}$ to $15 \mathrm{~cm}$ and at a distance of $15 \mathrm{~cm}$ from the trunk of the vines, in three replications. Three collected soil samples from one combination were pooled.

\section{Determination of the number of spores of mycorrhizal fungi in the rhizosphere soil}

The samples of soil collected from the rhizosphere of Solaris and Regent grapevines were used to weigh out $100 \mathrm{~g}$ portions, per treatment, for further analyses. The plant material prepared in this way was placed in containers and made up to $1 \mathrm{~L}$ with tap water. The resulting suspensions were shaken for approx. $10 \mathrm{~min}$. and then placed in a refrigerator at $4^{\circ} \mathrm{C}$ for $24 \mathrm{~h}$. After that time, the soil solutions were filtered through a column of sieves $(0.5 \mathrm{~mm}, 0.125 \mathrm{~mm}, 0.063 \mathrm{~mm}$ and $0.045 \mathrm{~mm}$ ), and the fractions of soil remaining on the successive sieves were washed away with distilled water into Petri dishes $(120 \mathrm{~mm})$, to which sucrose (5 g per dish) was added. The prepared samples were examined under a Nikon SMZ 800 stereomicroscope, and the spores of mycorrhizal fungi present in them were picked out and counted per $100 \mathrm{~g}$ of rhizosphere soil (Błaszkowski, 2003).

\section{Identification of spores of AMF}

The spores of mycorrhizal fungi obtained for the determination of spore numbers were subjected to identification by examining microscopic specimens. The microscopic specimens of the spores were prepared by placing, on a glass slide, one drop each of the PVLG reagent (a mixture of polyvinyl alcohol, lactic acid, glycerol and distilled water), and a 1:5 mixture of PVLG and Melzer's reagent (aqueous solution of chloral hydrate, potassium iodide and iodine), in which the isolated spores were then placed and covered with a cover slip. PVLG and Melzer's reagent were prepared from commercial reagents (Sigma-Aldrich ${ }^{\circledR}$ ). The spores on the prepared microscope slides were examined, identified, described and photographed (Błaszkowski, 2003, 2012).

\section{Statistical analysis}

The results were statistically analysed using two-factorial analysis of variance. Multiple comparisons of the means for the combinations were performed with Tukey's test, at a significance level of $\alpha=0.05$ using STATISTICA v. 10 software (StatSoft Inc., 2011).

\section{RESULTS}

The results of the study reveal positive effects of the applied bioproducts on the occurrence and diversity of species of mycorrhizal fungi and the number of spores of AMF in the rhizosphere of Solaris and Regent grapevine plants.

Two species of AMF, namely Claroideoglomus claroideum and Funneliformis caledonium, were identified in the control samples of rhizosphere soil taken from the root zone of the cultivar Solaris, and only F. caledonium was identified in the rhizosphere soil from the cultivar Regent.

The use of the bioproducts Ausma, Bioilsa and BF Ekomix on their own (applied separately) contributed to the increased number of AMF species (four to five) in the rhizosphere soil, in comparison with the rhizosphere soil fertilised with NPK, in which only one species, C. claroideum, was found (Table 1).

The use of the bioproducts Ausma, Bioilsa and BF Ekomix alone increased the number of AMF species in the rhizosphere soil compared to the rhizosphere soil fertilised with NPK, in which case only one AMF species, C. claroideum, was found (Table 1). In the rhizosphere of the grapevine plants of the cultivars Solaris and Regent, almost the same species of mycorrhizal fungi were identified in the NPK control under the influence of the applied bioproducts, and following the combined application of the bioproducts with standard NPK fertilisation.

Fertilisation of the plants with standard mineral fertilisation limited the colonisation by a greater number of species of mycorrhizal fungi in the rhizosphere of the grapevine varieties studied. Only one species of mycorrhizal fungus $-C$. claroideum - was found in the combinations involving the use of NPK, NPK + Ausma, and NPK + BF Ekomix; another fungus $-F$. caledonium - was found in the combination NPK + Bioilsa, while in the combination NPK + manure both of the two species of fungi were present for Solaris. For Regent, C. claroideum and Glomus macrocarpum were found in the combination NPK + manure.

In addition, the tested bioproducts had a favourable effect on the number of spores obtained from the rhizosphere soil of the grapevine cultivars. The highest number of spores in the rhizosphere soil of the cultivar Regent had formed and was recorded in combinations following the application of the bioproduct BF Ekomix applied separately (Table 2).

The highest number of spores in the case of Solaris was found after treating plants with the bioproduct Bioilsa. The lowest numbers of spores were recorded in the NPK treatments. The numbers of spores in the NPK treatments combined with bioproducts were lower than when the bioproducts were applied separately, both for Solaris and Regent cultivars, across the individual seasons (Table 2).

\section{DISCUSSION}

Among the species of arbuscular mycorrhizal fungi identified in the analysed samples were fungi from the order Glomerales: F. caledonium, Glomus aggregatum, G. macrocarpum, Rhizophagus intraradices and C. claroideum, and one species of the family Gigasporaceae - Gigaspora margarita. Almost all the samples of rhizosphere soil (except NPK + Bioilsa) were found to contain the species C. claroideum, with the species $F$. caledonium also occurring in numbers. In this study, the AMF species diversity in the rhizosphere was low (one to five species of mycorrhizal fungi), which could have been caused by the slightly acidic soil ( $\mathrm{pH}$ 6.0) 
in which the plants were grown. Other authors have also observed a similar tendency, i.e. that low soil $\mathrm{pH}$ decreases the diversity of AMF species (Ocete et al., 2015). Among the species of arbuscular fungi colonising the roots of the wild grapevine, $V$. vinifera L. ssp. sylvestris (Gmelin) Hegi, growing in different regions of the Basque Country (Spain), the cited authors identified a number of AMF taxa, of which one of the most common was $C$. claroideum. They also

TABLE 1

Species of AMF identified in the rhizosphere of 'Solaris' and 'Regent' grapevine cultivars following the use of bioproducts (season 2014)

\begin{tabular}{|c|c|c|}
\hline \multirow[b]{2}{*}{ Treatment } & \multicolumn{2}{|c|}{ Species of arbuscular mycorrhizal fungi (AMF) } \\
\hline & Solaris & Regent \\
\hline 1. Control & $\begin{array}{l}\text { F. caledonium } \\
\text { C. claroideum }\end{array}$ & F. caledonium \\
\hline 2. NPK & C. claroideum & C. claroideum \\
\hline 3. Ausma & $\begin{array}{l}\text { C. claroideum } \\
\text { F. caledonium } \\
\text { G. margarita } \\
\text { G. aggregatum } \\
\text { R. intraradices }\end{array}$ & $\begin{array}{l}\text { C. claroideum } \\
\text { F. caledonium } \\
\text { G. margarita } \\
\text { G. macrocarpum }\end{array}$ \\
\hline 4. NPK + Ausma & C. claroideum & C. claroideum \\
\hline 5. Bioilsa & $\begin{array}{l}\text { C. claroideum } \\
\text { F. caledonium } \\
\text { G. margarita } \\
\text { G.macrocarpum }\end{array}$ & $\begin{array}{l}\text { C. claroideum } \\
\text { F. caledonium } \\
\text { G. margarita } \\
\text { G. macrocarpum }\end{array}$ \\
\hline 6. NPK + Bioilsa & F. caledonium & F. caledonium \\
\hline 7. Manure & C. claroideum & C. claroideum \\
\hline 8. NPK + Manure & $\begin{array}{l}\text { C. claroideum } \\
\text { F. caledonium }\end{array}$ & $\begin{array}{l}\text { C. claroideum } \\
\text { G. macrocarpum }\end{array}$ \\
\hline 9. BF Ekomix & $\begin{array}{l}\text { C. claroideum } \\
\text { F. caledonium } \\
\text { G. margarita } \\
\text { R. intraradices }\end{array}$ & $\begin{array}{l}\text { C. claroideum } \\
\text { F. caledonium } \\
\text { G. margarita } \\
\text { G. macrocarpum }\end{array}$ \\
\hline 10. NPK + BF Ekomix & C. claroideum & C. claroideum \\
\hline
\end{tabular}

TABLE 2

Effect of bioproducts on the number of spores per $100 \mathrm{~g}$ of soil in the rhizosphere soil of 'Solaris' and 'Regent' grapevine cultivars

\begin{tabular}{|c|c|c|c|c|c|c|c|c|}
\hline \multirow[b]{2}{*}{ Treatment } & \multicolumn{2}{|c|}{2012} & \multicolumn{2}{|c|}{2014} & \multicolumn{2}{|c|}{2016} & \multirow{2}{*}{$\frac{\text { Ave. } \pm \text { SD }}{\text { Solaris }}$} & \multirow{2}{*}{$\frac{\text { Ave. } \pm \text { SD }}{\text { Regent }}$} \\
\hline & Solaris & Regent & Solaris & Regent & Solaris & Regent & & \\
\hline 1. Control & $28 \mathrm{a}$ & $33 \mathrm{ab}$ & $36 b-d$ & 40b-e & $40 b-e$ & $50 e-h$ & $35 \pm 3$ & $41 \pm 5$ \\
\hline 2. NPK & $29 \mathrm{ab}$ & $25 \mathrm{a}$ & $23 \mathrm{a}$ & $35 b-d$ & $29 a$ & $33 a b$ & $27 \pm 2$ & $31 \pm 2$ \\
\hline 3. Ausma & $47 \mathrm{de}$ & 48de & $53 \mathrm{f}-\mathrm{h}$ & $52 \mathrm{~d}-\mathrm{g}$ & $64 \mathrm{ij}$ & $57 g-i$ & $\mathbf{5 5} \pm \mathbf{3}$ & $53 \pm 4$ \\
\hline 4. NPK + Ausma & $26 \mathrm{a}$ & $38 b-d$ & $31 \mathrm{ab}$ & $45 c-g$ & $27 \mathrm{a}$ & $52 \mathrm{f}-\mathrm{h}$ & $28 \pm 2$ & $45 \pm 4$ \\
\hline 5. Bioilsa & $62 \mathrm{~g}$ & $50 \mathrm{ef}$ & $68 \mathrm{ij}$ & $55 \mathrm{gh}$ & $72 \mathrm{j}$ & $57 g-i$ & $67 \pm 2$ & $54 \pm 3$ \\
\hline 6. NPK + Bioilsa & 46de & $33 \mathrm{ab}$ & $55 \mathrm{gh}$ & $34 a-c$ & $60 \mathrm{hi}$ & $35 a-c$ & $54 \pm 3$ & $34 \pm 5$ \\
\hline 7. Manure & $53 e-g$ & $45 c-e$ & $61 \mathrm{hi}$ & $36 b-d$ & $63 \mathrm{ij}$ & $47 d-g$ & $59 \pm 4$ & $43 \pm 3$ \\
\hline 8. NPK + Manure & $31 \mathrm{ab}$ & $29 \mathrm{ab}$ & $53 \mathrm{f}-\mathrm{h}$ & $45 c-g$ & $41 b-f$ & $41 b-e$ & $42 \pm 4$ & $38 \pm 3$ \\
\hline 9. BF Ekomix & $47 \mathrm{de}$ & $59 \mathrm{fg}$ & $42 b-f$ & $78 \mathrm{j}$ & $55 \mathrm{gi}$ & $72 \mathrm{j}$ & $48 \pm 3$ & $70 \pm 3$ \\
\hline 10. NPK + BF Ekomix & 46de & $35 a-c$ & $47 d-g$ & $38 b-d$ & $40 b-d$ & $44 c-f$ & $44 \pm 3$ & $39 \pm 3$ \\
\hline
\end{tabular}

Means within a year followed by the same letter do not differ significantly, at $\mathrm{p}=0.05$, according to Tukey's multiple test. 
found the presence of $G$. margarita and fungi of the genus Funneliformis. The effect of soil $\mathrm{pH}$ on the structure of AMF biodiversity has been observed in other studies concerned with grapevines (Balestrini et al., 2010), as well as in the case of other plant species (An et al., 2008). The arbuscular fungus $C$. claroideum, identified in this study, has also been found in the soil collected from under grapevine plants of the cultivar Pinot Noir grown in four vineyards in Oregon (USA) (Schreiner \& Mihara 2009). These authors also identified a few other species of the families Glomeraceae (e.g. Funneliformis mosseae), Acaulosporaceae (numerous fungi of the genus Acaulospora) and Gigasporaceae (Scutellospora calospora). The dominance of fungi belonging to Glomerales, mainly of the genus Glomus sensu lato, in the rhizosphere soil of grapevines has also been observed. Balestrini et al. (2010), examining AMF of grapevines, revealed that the dominant fungi were those classified as Glomus and belonging to different groups, while other families, such as Gigasporaceae or Acaulosporaceae, occurred much less frequently.

The analysis of the results indicates that the application of the Ausma, Bioilsa and BF Ekomix bioproducts on their own (applied separately), without NPK fertilisation, had a stimulating effect on increasing the number of species of arbuscular mycorrhizal fungi (AMF) in the rhizosphere of both grapevine cultivars. Depending on the bioproduct used, the presence of four to five AMF species was observed in the rhizosphere of grapevines. After fertilisation with NPK in combination with the bioproducts, only one AMF species was found in the cultivar Solaris. This result indicates a limiting effect of NPK fertilisation on the occurrence of several AMF species, in comparison with the control combination and fertilisation with the bioproducts only. Similar results have been obtained by Verbruggen et al. (2010), who found that the average number of AMF taxa in organically managed fields (6.4) was higher than in conventionally managed fields (3.9). In addition, it has been found that phosphorus fertilisation lowers the extent of AMF root colonisation (Jansa et al., 2006). It can therefore be assumed that in the presence of a fertiliser, the grapevine does not need to enter into symbiosis with AMF. It is also possible that the NPK fertiliser directly affects the formation of AMF spores, but such assumptions should be confirmed by further research.

In the cultivars Regent and Solaris, the occurrence of one AMF species was observed, as in the control combination, after fertilisation with the bioproducts in combination with NPK. After using manure together with NPK fertilisation, an increase in the number of AMF species was observed, in comparison with the use of manure alone. The application of the bioproducts on their own (applied separately) increased the diversity of AMF in the rhizosphere of both cultivars up to four or five species, in comparison with standard NPK fertilisation, where only one species was observed.

The analysis of the composition of AMF species in individual treatments indicates that the AMF species most tolerant to NPK fertilisation were C. claroideum and $F$. caledonium. The large number of spores in the soil treated with BF Ekomix may indicate a beneficial effect of this bioproduct on the development of AMF in the rhizosphere of the cultivar Regent, greater than in the cultivar Solaris.
An explanation of this phenomenon requires further research involving a larger number of grapevine cultivars.

The study demonstrated the beneficial effects of the pine needle extract in Ausma and the extracts of marine algae and of humic acids present in the bioproduct BF Ekomix on the number of AMF species. However, the strongest effects were produced by the bioproduct Ausma in the cultivar Solaris (five AMF species) and Regent (four AMF species), as well as by the application of Bioilsa and BF Ekomix on their own (applied separately) in the case of both Solaris and Regent (four AMF species). The beneficial effects of the compounds contained in marine algae have been proven by other authors working with agricultural plants. Mannitol and other compounds contained in Laminaria japonica stimulated the growth of the mycorrhizal fungus G. margarita, and the extent of colonisation of the roots of trifoliate orange (Kuwada et al., 2005). Humic acids applied to the soil stimulated the colonisation of the roots of maize by mycorrhizal fungi (Gryndler et al., 2005).

In a study by Sas-Paszt et al. (2019) on the same site, NPK fertilisation limited the degree of mycorrhizal association in the roots of Solaris and Regent to the greatest extent. Similar correlations were found for the number of spores in $100 \mathrm{~g}$ of soil in the current study.

In this study, the formation of spores in the rhizosphere of the two grapevine cultivars treated with the bioproducts on their own (applied separately) was different from that observed after the combined application of these bioproducts with standard NPK fertilisation. The number of spores per $100 \mathrm{~g}$ of soil ranged from 23.0 to 78.0 , indicating a greater spore-forming ability compared to AMF-colonising grapevine plants of the cultivar Pinot Noir grown in four vineyards in Oregon (USA), where the number of spores isolated from the soil, in most cases, did not exceed 15 spores per $100 \mathrm{~g}$ of soil in the absence of bioproducts (Schreiner \& Mihara 2009). The bioproducts that have a positive effect on the number of spores in the rhizosphere of grapevine plants are Bioilsa (72.0) for Solaris and BF Ekomix for Regent (78.0).

Previous studies had found that the application of AMF had a positive effect on the growth of grapevine plants. Khalil (2013) reported that grapevine rootstocks ( $V$. vinifera L.) inoculated with $R$. intraradices exhibited higher growth parameters (plant height, stem diameter, shoot and root biomass) compared to non-inoculated plants. The higher crop performance in inoculated grapevine was attributed to a lower concentration of $\mathrm{Na}$ and $\mathrm{Cl}$, higher $\mathrm{K}$ and $\mathrm{Mg}$ concentrations in the leaf tissue, and also a higher $\mathrm{K} / \mathrm{Na}$ ratio.

This study shows that all of the bioproducts tested Ausma, Bioilsa and BF Ekomix - promoted the formation of a greater number of AMF species in comparison to NPK fertilisation and the combined application of NPK with these bioproducts. The species of AMF whose presence was found only in the soil treated with the bioproducts had probably existed in the soil earlier, but in numbers undetectable by the methods used. The application of the bioproducts created conditions suitable for their growth and development, as a result of which they could be identified based on the morphological features of their spores. 


\section{CONCLUSIONS}

The applied bioproducts, Ausma, Bioilsa and BF-Ecomix, contributed to an increase in the occurrence and number of species of mycorrhizal fungi in the rhizosphere soil of grapevines. The most frequently occurring AMF species was C. claroideum. The bioproduct BF Ekomix had the greatest effect on increasing the number of AMF spores obtained from the rhizosphere of the Regent grapevine plants, while the application of Bioilsa contributed to the formation of the largest number of spores in the rhizosphere of the Solaris cultivar. Standard NPK fertilisation reduced the formation of AMF spores and AMF species in the rhizosphere of grapevine plants of cr. Regent and Solaris.

\section{LITERATURE CITED}

Allen, M.F., 2011. Linking water and nutrients through the vadose zone: A fungal interface between the soil and plant systems. J. Arid Land 3, 155-163.

An, G.-H., Miyakawa, S., Kawahara, A., Osaki, M. \& Ezawa, T., 2008. Community structure of arbuscular mycorrhizal fungi associated with pioneer grass species Miscanthus sinensis in acid sulfate soils: Habitat segregation along $\mathrm{pH}$ gradients. Soil Sci. Plant Nutr. 54, 517-528.

Balestrini, R., Magurno, F., Walker, C., Lumini, E. \& Bianciotto, V., 2010. Cohorts of arbuscular mycorrhizal fungi (AMF) in Vitis vinifera, a typical Mediterranean fruit crop. Env. Microbiol. Rep. 2, 594-604.

Berg, G., Zachow, C., Müller, H., Philipps, J. \& Tilcher, R., 2013. Nextgeneration bio-products sowing the seeds of success for sustainable agriculture. Agronomy 3, 648-656. doi:10.3390/agronomy3040648

Bhardwaj, D., Ansari, M.W., Sahoo, R.K. \& Tuteja, N., 2014. Biofertilizers function as key player in sustainable agriculture by improving soil fertility, plant tolerance and crop productivity. Microb. Cell Fact. 13, \#66.

Błaszkowski, J., 2003. Arbuscular mycorrhizal fungi (Glomeromycota). Endogone and Complexipes species deposited in the Department of Plant Pathology, University of Agriculture in Szczecin, Poland. Online: http:// www.zor.zut.edu.pl/Glomeromycota/.

Błaszkowski, J., 2012. Glomeromycota. W. Szafer Institute of Botany, Polish Academy of Sciences, Kraków.

Boyer, L.R., Brain, P., Xu, X.M. \& Jeffries, P., 2015. Inoculation of droughtstressed strawberry with a mixed inoculum of two arbuscular mycorrhizal fungi: Effects on population dynamics of fungal species in roots and consequential plant tolerance to water deficiency. Mycorrhiza 25, 215-227.

Cangahuala-Inocente, G., Da Silva, M.F., Johnson, J.-M., Manga, A., Van Tuinen, D., Henry, C., Lovato, P.E. \& Dumas-Gaudot, E., 2011. Arbuscular mycorrhizal symbiosis elicits proteome responses opposite of P-starvation in $\mathrm{SO} 4$ grapevine rootstock upon root colonisation with two Glomus species. Mycorrhiza 21, 473-493.

Del Val, C., Barea, J.M., \& Azcon-Aguilar, C., 1999. Diversity of arbuscular mycorrhizal fungus populations in heavy-metal-contaminated soils. Appl. Environ. Microbiol. 65, 718-723.

Derkowska, E., Sas-Paszt, L., Głuszek, S., Trzciński, P., Przybył, M. \& Frąc, M., 2017. Effects of treatment of apple trees with various bioproducts on tree growth and occurrence of mycorrhizal fungi in the roots. Acta Sci. Pol. Hort. Cult. 16, 75-83.

Gaidos, S., 2014. Grape expectations: Climate change is already transforming the wine industry. Sci. News 185, 20-24.

Gryndler, M., Hršelová, H., Sudová, R., Gryndlerová, H., Řezáčová, V. \& Merhautová, V., 2005. Hyphal growth and mycorrhiza formation by the arbuscular mycorrhizal fungus Glomus claroideum BEG 23 is stimulated by humic substances. Mycorrhiza 15, 483-488.
Hannah, L., Roehrdanz, P.R., Ikegami, M., Shepard, A.V., Shaw, M.R., Tabor, G., Zhi, L., Marquet, P.A. \& Hijmans, R.J., 2013. Climate change, wine, and conservation. P. Natl. Acad. Sci. 110, 6907-6912.

Hao, Z., Fayolle, L., Van Tuinen, D., Chatagnier, O., Li X., Gianinazzi, S. \& Gianinazzi-Pearson, V., 2012. Local and systemic mycorrhiza-induced protection against the ectoparasitic nematode Xiphinema index involves priming of defence gene responses in grapevine. J. Exp. Bot. 63, 1-16.

Izajasz-Parchańska, M., Cioch, M. \& Tuszyński, T., 2014. Monitoring parametrów dojrzałości technologicznej winogron na terenie małopolskiej Winnicy Srebrna Góra, w sezonie wegetacyjnym 2012. [Monitoring parameters of technological maturity of grapes in Małopolska Silver Mountain vineyard in the growing season 2012]. Acta Agrophysica 21, 263278. [In Polish]

Jansa, J., Mozafar, A., Anken, T., Ruh, R., Sanders, I. \& Frossard, E., 2002. Diversity and structure of AMF communities as affected by tillage in a temperate soil. Mycorrhiza 12, 225-234.

Jansa, J., Wiemken, A. \& Frossard, E., 2006. The effects of agricultural practices on arbuscular mycorrhizal fungi. Geological Society, London, Special Publications 266, 89-115.

Khalil, H.A., 2013. Influence of vesicular-arbuscula mycorrhizal fungi (Glomus spp.) on the response of grapevines rootstocks to salt stress. Asian J. Crop Sci. 5, 393-404.

Kohler, J., Roldán, A., Campoy, M. \& Caravaca, F., 2017. Unraveling the role of hyphal networks from arbuscular mycorrhizal fungi in aggregate stabilization of semiarid soils with different textures and carbonate contents. Plant Soil 410, 273-281.

Kopeć, B., 2009. Uwarunkowania termiczne wegetacji winorośli na obszarze południowo-wschodniej Polski. [Thermal conditions of grape vegetation in south-eastern Poland]. Infrastruktura i Ekologia Terenów Wiejskich 4, 251-262. [In Polish]

Krośniak, M., Gąstoł, M., Banach, P. \& Pytel, A., 2009. Wybrane parametry jakościowe winogron uprawianych w Polsce południowej. [Qualitative parameters of grapes grown in southern Poland]. Żywność Nauka Technologia Jakość 16, 116-121. [In Polish]

Kuwada, K., Kuramoto, M., Utamura, M., Matsushita, I., Shibata, Y. \& Ishii, T., 2005. Effect of mannitol from Laminaria japonica, other sugar alcohols, and marine alga polysaccharides on in vitro hyphal growth of Gigaspora margarita and root colonization of trifoliate orange. Plant Soil $276,279-286$

Lenoir, I., Fontaine, J. \& Lounès-Hadj Sahraoui, A., 2016. Arbuscular mycorrhizal fungal responses to abiotic stresses: A review. Phytochemistry 123, 4-15.

Lisek, J., Sas-Paszt, L., Derkowska, E., Mrowicki, T., Przybył, M. \& Frąc, M., 2016. Growth, yielding and healthiness of grapevine cultivars 'Solaris' and 'Regent' in response to fertilizers and biostimulants. J. Hortic. Res. 24, $49-60$

Marschner, H. \& Dell, B., 1994. Nutrient uptake in mycorrhizal symbiosis. Plant Soil 159, 89-102.

Mercado-Blanco, J. \& Bakker, P.A.H.M., 2007. Interactions between plants and beneficial Pseudomonas spp.: Exploiting bacterial traits for crop protection. Antonie van Leeuwenhoek 92, 367-389.

Nogales, A., Aguirreolea, J., Santa María, E., Camprubí, A. \& Calvet, C., 2009. Response of mycorrhizal grapevine to Armillaria mellea inoculation: Disease development and polyamines. Plant Soil 317, 177-187.

Nouri, E., Breuillin-Sessoms, F., Feller, U. \& Reinhardt, D., 2014. Phosphorus and nitrogen regulate arbuscular mycorrhizal symbiosis in petunia hybrida. PLOS One 9, e90841. 
Ocete, R., Armendáriz, I., Cantos, M., Álvarez, D. \& Azcón, R., 2015. Ecological characterization of wild grapevine habitats focused on arbuscular mycorrhizal symbiosis. Vitis 54, 207-211.

Prasad, R., Bhola, D., Akdi, K., Cruz, C., Sairam, K.V.S.S., Tuteja, N. \& Varma, A., 2017 Introduction to mycorrhiza: Historical development. In: Varma, A., Prasad, R. \& Tuteja, N. (eds). Mycorrhiza - Function, diversity, state of the art. Springer International Publishing AG, Cham. pp. $1-7$.

Sas-Paszt, L., Malusà, E., Sumorok, B., Canfora, L., Derkowska, E. \& Głuszek, S., 2015. The influence of bioproducts on mycorrhizal occurrence and diversity in the rhizosphere of strawberry plants under controlled conditions. Adv. Microbiol. 5, 40-53.

Sas-Paszt, L., Głuszek, S., Derkowska, E., Sumorok, B., Lisek, J., Trzciński, P., Lisek, A., Frąc, M., Sitarek, M. \& Przybył, M., 2019. Occurrence of arbuscular mycorrhizal fungi in the roots of two grapevine cultivars in response to bioproducts. S. Afr. J. Enol. Vitic. 40, 1-4.

Schreiner, R.P. \& Mihara, K.L., 2009. The diversity of arbuscular mycorrhizal fungi amplified from grapevine roots (Vitis vinifera L.) in Oregon vineyards is seasonally stable and influenced by soil and vine age. Mycologia 101, 599-611

Schüßler, A. \& Walker, C., 2010. The Glomeromycota. A species list with new families and new genera. Gloucester, UK.

Smith, S.E. \& Read, D., 2008 ( $3^{\text {rd }}$ ed). The symbionts forming arbuscular mycorrhizas. In: name(s) of editor(s) required (eds). Mycorrhizal symbiosis. Academic Press, London. pp. 13 - 41

Statsoft Inc., 2011. Statistica, (data analysis software system), version 10. Tulsa.

Sumorok, B., Sas-Paszt, L., Głuszek, S., Derkowska, E. \& Żurawicz, E., 2011. The effect of mycorrhization and mulching of apple trees 'Gold Milenium' and blackcurrant bushes 'Tiben' on the occurrence of arbuscular mycorrhizal fungi. J. Fruit Ornam. Plant Res. 19, 35-49.

Tarko, T., Duda-Chodak, A., Sroka, P., Satora, P. \& Jurasz, E., 2008. Physicochemical and antioxidant properties of selected Polish grape and fruit wines. Acta Sci. Pol. - Technol. Aliment. 7, 35-34.
Tarozzi, A., Cocchiola, M., D’evoli, L., Franco, F., Hrelia, P., Gabrielli, P., Lucarini, M., Aguzzi, A. \& Lombardi-Boccia, G., 2008. Fruit attributes, phenolic compounds, antioxidant and antiproliferative activity of strawberries (Fragaria ananassa 'Favette') grown by biodynamic and conventional agriculture methods. Acta Hortic. 873, 289-294.

Theocharis, A., Hand, P., Pole, J., Cevik, V., Fisarakis, I. \& Henderson, J., 2010. Study of genetic diversity among inter-intraspecific hybrids and original grapevine varieties using AFLP molecular markers. Aust. J. Crop Sci. 4, 1-8.

Thirkell, T.J., Cameron, D.D. \& Hodge, A., 2016. Resolving the 'nitrogen paradox' of arbuscular mycorrhizas: Fertilization with organic matter brings considerable benefits for plant nutrition and growth. Plant Cell Environ. 39, 1683-1690.

Torres, N., Goicoechea, N. \& Antolín, M.C., 2015. Antioxidant properties of leaves from different accessions of grapevine (Vitis vinifera L.) cv. Tempranillo after applying biotic and/or environmental modulator factors. Ind. Crop Prod. 76, 77-85.

Vassilev, N., Vassileva, M., Lopez, A., Martos, V., Reyes, A., Maksimovic, I., Eichler-Löbermann, B. \& Malusà, E., 2015. Unexploited potential of some biotechnological techniques for biofertilizer production and formulation. Appl. Microbiol. Biotechnol. 99, 4983-4996.

Verbruggen, E., Roling, W.F.M., Gamper, H.A., Kowalchuk, G.A., Verhoef, H.A. \& Vander Heijden, M.G.A., 2010. Positive effects of organic farming on below-ground mutualists: Large-scale comparison of mycorrhizal fungal communities in agricultural soils. New Phytol. 186, 968-979.

Wezel, A., Casagrande, M., Celette, F., Vian, J.F., Ferrer, A. \& Peigné, J., 2014. Agroecological practices for sustainable agriculture. A review. Agron. Sustain. Dev. 34, 1-20.

Wright, S.F. \& Upadhyaya, A., 1998. A survey of soils for aggregate stability and glomalin, a glycoprotein produced by hyphae of arbuscular mycorrhizal fungi. Plant Soil 198, 97-107.

Zhang, H., Liu, Z., Chen, H. \& Tang, M., 2016. Symbiosis of arbuscular mycorrhizal fungi and Robinia pseudoacacia L. improves root tensile strength and soil aggregate stability. PLOS One 11, e0153378. 